\title{
NAS TRAMAS DO RAP NACIONAL: \\ HISTÓRIAS DE RIMAS E BATIDAS
}

\section{IN THE PLOTS OF NATIONAL RAP: \\ HISTORY OF RHYMES AND BEATS}

Carolina Vasconcelos Pitanga*

TEPERMAN, Ricardo. Se liga no som: as transformações do rap no Brasil. São Paulo: Claro Enigma, 2015, 177 p.

Se liga no som: as transformações do rap no Brasil é um livro lançado recentemente pelo selo Claro Enigma, publicação do grupo editorial Companhia das Letras. 0 livro faz parte da Coleção Agenda Brasileira, que tem aglutinado outros títulos voltados a pensar o Brasil e suas especificidades históricas, sociais e culturais, como por exemplo: Nem preto nem branco, muito pelo contrário Lilia Moritz Schwarcz) (2012); As figuras do sagrado: entre o público e o privado na religiosidade brasileira (Maria Lucia Montes)(2013); Índios no Brasil: história, direitos e cidadania (Manuela Carneiro da Cunha) (2012); e Cidadania, um projeto em construção: minorias, justiça e direitos (Orgs. André Botelho e Lilia Moritz Schwarcz) (2012).

A publicação é de importância fundamental se for considerada a recente ascensão do rap e do movimento hip hop na cena artística brasileira. 0 crescimento do número de artistas ligados ao rap e a divulgação dos seus trabalhos nos principais meios de comunicação remetem à necessidade de pensar as possíveis origens desse gênero musical e sua disseminação pelos quatro hemisférios. Como se não bastasse a riqueza e a novidade referentes aos seus elementos endêmicos, nota-se que o

\footnotetext{
* Doutoranda em Ciências Sociais na Universidade Federal do Maranhão - UFMA (São Luís/MA/Brasil). Pesquisa, atualmente, a construção do gênero nas campanhas publicitárias e realiza estudos dentro da Sociologia da Imagem. carol.pitanga@yahoo.com.br.
} 
rap, enquanto gênero musical e expressão, suscita uma série de questões relacionadas aos processos de criação e à diversidade de vivências artísticas experimentadas pelos seus produtores.

De modo geral, ao pensar no rap, uma série de imagens nos vêm à cabeça: garotos com um visual próprio, com bonés de aba reta, calças largas, blusas com mensagens, atitude violenta etc. Mas que gênero musical é esse, saído do meio underground, em que predominava a crítica à indústria do entretenimento, e que atualmente tem tomado conta das principais festas de jovens da classe média e marcado presença nas principais rádios e nos canais televisivos?

Com o intuito de pensar essas e outras questões, o livro de Ricardo Teperman nos ajuda a compreender um pouco mais algumas nuances e idiossincrasias do rap, considerando sua recente atuação como produto no mercado musical.

Utilizando-se de uma redação acessível e estimulante, o autor percorre localidades e temporalidades diversas com o intuito de apresentar o caráter singular e multifacetado do rap ao longo de sua história.

Logo de início, o livro descontrói noções arraigadas sobre música e os seus diferentes gêneros. Ao colocar a música - ou melhor, os sons - como elemento constituinte das relações cotidianas, Ricardo Teperman nos orienta a adentrar o universo do rap considerando o significado dos principais termos falados e os contextos sociopolíticos que engendraram o mítico surgimento do movimento hip hop.

Levando em consideração as histórias sobre o nascimento do rap - que ocorreu possivelmente no distrito de Nova York chamado Bronx, conhecido por ser a área com os menores índices sociais da cidade, na década de 1970 - até o surgimento da nova escola do rap, o autor define o rap como algo que problematiza e reorganiza os aspectos clássicos da produção musical no que se refere à produção, à disseminação e ao consumo da música. Esse é, justamente, o elemento surpresa do livro: suscitar questões sobre a música e, sobretudo, perceber o rap enquanto expressão musical que está além das fronteiras de classificação da indústria fonográfica.

Esse aspecto se torna mais evidente nos capítulos “Rap é música?" e "Originalidade da cópia”. No primeiro, Teperman nos apresenta não só os aspectos musicais (como a produção dos beats e das rimas) que norteiam o processo de criação do DJ e do MC, mas também aprofunda uma discussão sobre como o rap faz da música um instrumento de transformação. Nesse sentido, longe de tentar compreender o rap simplesmente a partir de suas características internas, o autor relativiza a ideia de música pura e erudita, defendendo a seguinte premissa: a música, de um modo geral, e o rap, especificamente, não podem ser reduzidos à categoria de "apenas música”. A música não é totalmente autônoma, ela faz parte desse estar no mundo.

No capítulo seguinte, "Originalidade da cópia”, há um deslocamento da questão “Rap é música?" para "Essa música é ou não rap?" que foi exemplificado a partir do caso de dois rappers: o estadunidense Vanilla Ice (rapper branco sem vínculo com os guetos, que subiu ao pódio das paradas da Billboard em 1990) e o brasileiro Gabriel 0 Pensador (também branco e oriundo da classe média, que alcançou sucesso sem obter reconhecimento nas esferas de legitimação dos rappers). A polêmica toda gira em torno do fato de as músicas produzidas por músicos negros (como o jazz, o blues etc.) acabarem tendo mais divulgação 
quando atingem as camadas brancas e mais abastadas da sociedade. As consequências disso são, primeiramente, as acusações de falta de legitimidade da música que, no caso brasileiro, recaem sobre a ideia de que o rap seria uma cópia de um movimento originalmente nascido nos EUA.

Nos capítulos seguintes, Teperman discorre mais especificamente sobre os caminhos percorridos pelo rap no Brasil, considerando os grupos que conseguiram uma maior projeção no território nacional, tornando-se grandes referências para o rap nacional; entre eles estão os grupos Racionais Mc's, Facção Central, 509-E e o rapper G0G. Na década de 1990, a posição crítica - em relação à indústria do entretenimento e à mídia, as letras que remetem às cenas de crime e o discurso carregado de análise social em relação às periferias do país, que constituem o conteúdo dos principais grupos de rap - pode ser vista como um pano de fundo para a compreensão da forma como o rap era visto como algo marginalizado e feito com base em um conteúdo radical e contestatório.

De acordo com o autor, é a partir dos anos 2000 que acontece o surgimento do que costuma ser chamado de "nova escola" do rap. 0 estilo gangsta e o rap ostentação, o aumento da participação feminina no universo dos MC's, o rap produzido por indígenas (os Brô MC's misturam português com guarani e dão continuidade ao caráter crítico que costuma caracterizar a música rap) e a recente liberdade nas fronteiras do rap com outros gêneros musicais são alguns dos pontos apresentados no decorrer do livro e que, certamente, são o resultado de uma reflexão bastante lúcida sobre a mudança na forma de pensar e fazer rap.

A divergência entre as posturas legitimadas pela dita "cultura de rua" e as pos- sibilidades dadas pela indústria do entretenimento são reformuladas nas propostas de rappers como Cabral e Emicida. Os rappers da chamada "nova escola”, apesar de continuarem pautando suas rimas e atitudes a partir dos elementos ditos "da rua”, constroem uma carreira mais aberta às investidas do mercado e da grande mídia. Emicida e Criolo, por exemplo, que têm origem nas periferias de São Paulo e que alcançaram reconhecimento do grande público e do mercado, atualmente participam de reportagens em revistas conceituadas, são entrevistados em programa de televisão, recebem prêmios por suas músicas e realizam parcerias com cantores consagrados na MPB.

Se a atitude em relação ao rap mudou, é necessário pensar que houve, no Brasil, uma mudança também nas condições de vida de grande parte da população. É esse ponto que Teperman destaca ao refletir sobre o atual crescimento do rap como gênero musical voltado para o mercado. 0 rap já não é tão marginalizado como nos anos 1990, porque diversas transformações ocorreram no Brasil, tanto em relação aos aspectos econômicos quanto em relação ao acesso à educação e moradia por parte dos menos abastados.

Nesse sentido, a preocupação atual dos produtores é que o rap tenha mais espaço no mercado da música, que os grupos possam viver a partir da venda de álbuns e shows e que o rap seja ouvido não só nas periferias, mas em todo o território brasileiro.

Sendo assim, deve-se destacar que o livro é uma leitura obrigatória para quem se interessa não só pelo rap em si, mas pelos meandros da produção musical, em geral. Ao expor determinados conflitos e indefinições que envolvem a produção do rap no Brasil, e ao mesmo tempo trazer problematizações sobre o contexto social e cultural no 
qual esse gênero musical está sendo produzido, Teperman nos oferece a possibilidade de compreender a complexidade que envolve o rap que, longe de ser apenas mais uma expressão musical, é, sobretudo, um meio de transformação da realidade social.

Recebido em: 16/02/16

Aprovado em: 10/06/16 